УДК 32:321.7

https://doi.org/10.34142/24130060.2019.18.2.12

\title{
СУЧАСНА КОНЦЕПТАЛІЗАЦІЯ ГРОМАДЯНСЬКОГО СУСПІЛЬСТВА: РУХ ПОЗА МЕЖІ ІНСТИТУЦІОНАЛЬНОГО ПІДХОДУ
}

\section{В.Л. Пасісниченко, І.М. Пасісниченко}

Харківський національний педагогічний університет імені Г.С. Сковороди

У статті розглядається сучасна концептуалізація громадянського суспільства як реакиія на усвідомлення обмеженість його ліберальної теоретичної традииї з ї̈ спрощеним інституціональним ототожненням громадянського суспільства 3 добровільними асоиіаціями та НДО. Зокрема, аналізується заклик Дж. Александера відмовитись від фокусу виключно на формальних інституціях демократії. Цей рух поза інституиіональний підхід дозволяе відкрити другий культурний, вимір громадянського суспільства як солідарності спільноти, щзо спирається на иивільний культурний код всупереч нецивільному. В запропонованій теоретичній схемі бінарних культурних кодів громадянського суспільства детально відстежується просування з рівня мотивів діючого актора через рівень відносин до третього рівня інститутів, реальний зміст яких визначається відповідним сакральним культурним кодом. Доповнення інституційного рівня громадянського суспільства аналізом його культурного рівня також дозволяє дослідити більш складну взаємодію громадянського суспільства та демократії.

Ключові слова: соичіальні інститути, інституціональний аналіз, громадянське суспільство, культурний код.

\section{СОВРЕМЕННАЯ КОНЦЕПТУАЛИЗАЦИЯ ГРАЖДАНСКОГО ОБЩЕСТВА: ВЫХОД ЗА ПРЕДЕЛЫ ИНСТИТУЦИОНАЛЬНОГО ПОДХОДА}

\section{В.Л. Пасисниченко, И.Н. Пасисниченко}

В статье рассматривается современная концептуализаџия гражданского общества как реакция на осознание ограниченности его либеральной теоретической традищии с ее упрощенным институциональным отождествлением гражданского общества и добровольных ассочиащий и НГО. В частности, анализируется призыв Дж. Александера отказаться от акцента исключительно на формальных институциях демократии. Этот выход за пределы институционального подхода позволяет открыть другой культурный уровень гражданского общества як солидарности сообщества, которая опирается на циивильный культурный код в противоположность нецивильному коду. В предлагаемой теоретической схеме бинарных культурных кодов гражданского общества детально прослеживается движение с уровня мотивов действующего актора через уровень отношений $\kappa$ третьему уровню институтов, реальное содержание которых определяется соответствующим сакральным культурным кодом. Дополнение институционального уровня гражданского общества его культурным уровнем также позволяет исследовать более сложное взаимодействие гражданского общества $и$ демократии.

(C) В.Л. Пасісниченко, I.М. Пасісниченко, 2019 
Ключевые слова: сочиальные институты, институциональный анализ, гражданское общество, культурный код.

\title{
CONTEMPORARY CIVIL SOCIETY CONCEPTUALIZATION: GOING BEYOND INSTITUTIONAL APPROACH
}

\author{
V. Pasisnychenko, I. Pasisnychenko
}

This article reveals contemporary civil society conceptualization as a challenge to the restrictions of liberal theory simplistic equation of civil society with voluntary associations and NGOs. Such institutional vision of civil society was popular in 1990-th years in a period of civil society idea revival in the western social theory. For example, $R$. Putnem in his theory of social capital links a level of democracy and activity and number of voluntary associations.

Later this narrow institutional vision of civil society was challenged both by real practice and by studies that showed ruined effect of some civil institutions for democracy development. Therefore, it explains J. Alexander's proposal to reject a traditional focus on the formal institutions of democracy. Going beyond institutional approach opens another cultural level of civil society as a solidarity of community based on common values and cultural codes. J. Alexander's theoretical scheme of binary cultural codes is tracing how in a civil or uncivil code we are moving from motives through relations and finally to the third level of institutions with its particular content. In such way, we supplement civil society institutional level with civil society cultural level, which also includes a role of actor, his discourses and dominated cultural codes. That is, it is argued that J. Alexander's analysis of cultural codes does not begin traditionally from above, from the level of institutions, but from below, from the level of the individual, the individual as an active actor and his motives. From the corresponding specific code of motivation we pass to the second level of relationships and get that at the third level of institutions we have different contents of them with the same formal characteristics.

Finally, this reconceptualization of civil society beyond narrow institutionalism opens a perspective to study complicated relationships between civil society and democracy.

Key words: social institutions, institutional analyses, civil society, cultural code.

Постановка проблеми. Інститути відіграють важливу роль у соціальному житті і тому їх аналіз займає особливе місце в політології та соціології. Важливо також враховувати, що поняття «соціальний інститут» активно використовується в економічній теорії, яка мала значний вплив на бачення інститутів соціальними теоретиками. Це пояснює надзвичайну популярність i навіть домінування в дослідженнях методології інституціонального підходу. В політології серед багатьох прикладів застосування такого підходу можна відзначити і дослідження в питаннях розвитку громадянського суспільства. Акцент політологів на ролі формальних інститутів у розвитку демократії знайшов своє відображення у ліберальному баченні громадянського суспільства як сукупності добровільних асоціацій та недержавні інституцій (НДО). Однак нові реалії 
демонструють і певну обмеженість інституціонального аналізу громадянського суспільства та необхідність подолання абсолютизацію такої методології. У цьому контексті заслуговують на уваги дослідження в яких здійснюються спроби вийти за межі інституціонального підходу до громадянського суспільства. Зокрема, мова йде про нові підходи у концептуалізації громадянського суспільства, які пропонує американський соціолог Дж. Александер.

Аналіз актуальних досліджень. Наведені положення демонструють актуальність досліджень громадянського суспільства які доповнюють традиційний інституціональний рівень аналізу виходом на культурний контекст.

Мета статті полягає в аналізі теоретичних інновацій у подоланні спрощеного інституціонального бачення громадянського суспільства на прикладі концепту бінарних культурних кодів Дж Александера.

Виклад основного матеріалу. Сучасний етап відродження ідеї громадянського суспільства на Заході датується 1990-ми роками, коли це поняття жваво підхопила західна соціальна теорія. Саме тут ми зустрічаємо спрощене бачення громадянського суспільства, що ототожнює його 3 демократією та 3 добровільні асоціації й НДО. Воно походило 3 ліберальної традиції громадянського суспільства, що стала домінуючою. Ї̈̈ сучасний варіант представили «нео-токвіліанці» Ф. Фукуяма, Л. Даймонд та Р. Патнем. Особливого впливу набула теорія «соціального капіталу» Р. Патнама про залежність стану демократії від дієвості асоціацій, що напряму пов’язувала демократію із зрілістю соціального капіталу, тобто ГС. (Патнам, 2001). Така неоліберальна стратегія демократизації через розвиток інститутів громадянського суспільства вплинула як на теоретико-методологічні установки (зокрема, транзитологіï) так і стратегію дій західних агенцій впливу на посткомуністичному просторі.

Але надмірні очікування, пов’язані зі спрощеним інституційним баченням громадянського суспільства були швидко зруйновані сучасними 
реаліями. Невідповідність ототожнення демократії та громадянського суспільства виявилася після того як низка робіт у руслі аргументації Ш. Берман довела, що громадянське суспільство тільки не гарантує розвиток демократії, a, навпаки, його розвинуті інститути сприяли руйнуванню демократії та підтримці фашистських режимів у Німеччині та Італії. (Berman,1997). Міф про «святість» НДО як носіїв демократичних цінностей зруйнували також ті дослідники, які довели, що західні програми підтримки громадянського суспільства в Росії та Україні зробили ці НДО більш професійними організаціями, але це навіть загрожує розвиткові громадянського суспільства через посилення їх клієнтарно-патронажних відносин з донорами. Зазначимо, що все це відбувалося ще до того, як ми отримали приклади останніх років, коли інститути громадянського суспільства можуть широко використовуватися для досягненні спірних 3 точки зору демократії цілей.

У цьому контексті, розглядаючи проблему демократизації суспільства та розвитку громадянського суспільства, американський соціолог Джеффрі Александер пропонує інший підхід. Він є складовою його нової дисципліни культурної соціології, що розвивається ним 3 середини 1980-х років. (Cordero, Carballo, and Ossandón, 2008). Відмовившись від свого попереднього завдання створення загальної теорії діï у межах неофункціоналізму (Alexander, 1988), Дж. Александер пропонує переосмислення категорій культурного смислу та соціальної дії, коли культура наділяється відносною автономією, а суспільство розглядається як внутрішнє середовище дії. Важливим є акцент на тому, що культурні смисли та дії мають ознаки перфомансу, в наслідок чого його теорія соціальної дії стає насамперед теорією культурного перфомансу (Alexander, 2006).

Отже головна відмінність теоретичного підходу Дж. Александера полягає у відмові від фокусу на «формальних інституціях демократії». Традиційний інституційний підхід він називає «соціологічно нецікавим та нормативно некритичним» (Alexander, 2001, p. 374). Ця критика стосується i 
інститутів громадянського суспільства як волонтерських асоціацій токвіліанського або сучасного патнамовського типу. При цьому для Дж. Александера поняття громадянського суспільства $є$ центральною категорією яке він уточнює за допомогою терміну «цивільна сфера» та проголошує його особливим об’єктом для соціології. Отже поняття «цивільний» у нього є не тільки тотожним поняттю «демократичний» але набуває ширшого змісту коли виходить за межу формально інституційного бачення та залучає більш глибокі культурні структури та коди.

Звідсіля витікає пропонований Дж. Александером концепт бінарних культурних кодів громадянського суспільства - цивільний код vs нецівільний код (Alexander, 2001, p. 373). Ідея бінарності, запозичена ним у Дюргейма, означає постійне протистояння цих кодів, коли зміст одного з них неможливо зрозуміти без порівняння зі змістом іншого. Отже у будь-якому суспільстві потенційно існують два культурних коди - цивільний (демократичний) та нецивільний (недемократичний).

Інше важливе запозичення стосується розрізнення сакрального та профанного в соціології релігії того ж самого Дюркгейма. У теоретичній схемі Дж. Александера воно означає, що вибір на користь одного з двох культурних кодів визначається лише тим, який з них більшість спільноти сприймає як свій рідний і тому сакральний.

Необхідно підкреслити, що у Дж. Александера аналіз культурних кодів починається не традиційно зверху, з рівня інститутів, а знизу, з рівня людини, індивіда як діючого актора і його МОТИВІВ. Від відповідної конкретному коду мотивації ми переходимо до другого рівня ВІДНОСИН і отримуємо те, що на третьому рівні ИНСТИТУТІВ ми маємо різний їх зміст при однакових формальних характеристиках.

Тобто, корумповану владу ми отримуємо тоді, коли для більшості людей сакральним є нецивільний, недемократичний культурний код, починаючи 3 прийняття недемократичних мотивів. Дискурс такий: «ми знаємо, що у владі усі крадуть і це нормально; наш лідер теж краде але він же наш, свій». I 
навпаки, у суспільстві де більшість дотримуються мотивів цивільного демократичного культурного коду інституції наповнюються демократичним змістом та діють відповідно.

\section{Бінарні коди громадянського суспільства}

Цивільний

Цивільні мотиви

Активність

Незалежність

Раціональность

Розсудливість

Спокій

Самоконтроль

Реалістичність

Цивільні відносини

Відкритість Довіра

Критичність

Чесність

Альтруїзм

Правдивість

Прямота

Дружелюбність

Цивільні інститути

Слідування правилам

Закон

Рівність

Включеність

Публічність

Контракти

Групи

Офіси культурний код

МОТИВИ

Нецивільні мотиви
Пасивність
Залежність
Ірраціональність
Істеричність
Екзальтованість
Пристрастність
Викривлення

ВІДНОСИНИ

ІНСТИТУТИ
Нецівільний культурний код

Нецивільні відносини
Секретність
Підозрілість
Диференційованість критики
Особисті інтереси
Жадібність
Зрадливість
Розрахунок
Антагоністичність

Нецивільні інститути

Свавілля

Сила

Ієрархія

Винятковість

Персоніфікований характер

Узи відданості

Клани

Особисті зв'язки

Висновки та перспективи подальших досліджень. Отже у контексті виявленої обмеженості інституціонального підходу до ГС нові можливості для його концептуального переосмислення демонструє американський соціолог Дж. Александер. Він пов’ язує розв’язання парадоксів ГС з виходом на культурний контекст, тобто до інституцій ГС важливо додати наголос на 
ролі його акторів та відносин між ними з точки зору домінуючих культурних кодів, що відображаються в різних дискурсах.

Рух поза формальні інститути дозволяє відкрити другий культурний, вимір ГС як солідарності спільноти на основі єдиних цінностей та переконань. Головна роль у цьому процесі належить дискурсу ГС, як серцевині процесу демократизації, що спирається на цивільний культурний код всупереч нецивільному. Тому сучасна концептуалізація ГС вимагає перефокусування 3 формальних інституцій на вивчення домінуючих цінностей акторів та їх головних дискурсів. Доповнення інституційного виміру ГС аналізом його культурного виміру як солідарності спільноти на основі певного культурного коду також дозволяє замість спрощеного ототожнення дослідити більш складну взаємодію ГС та демократії.

\section{ЛІТЕРАТУРА}

1. Патнам, Р. 2001. Творення демократії: Традиції громадяньскої активності в сучасній Італії. Переклад з англійської В. Ющенко. Київ: Основи.

2. Berman, S. 1997. Civil society and the collapse of the Weimar republic. World Politics, 49(3), pp. 401-429.

3. Alexander, J. 1988. Neofunctionalism and After. Malden, Mass.: Blackwell.

4. Alexander, J. 2001. The long and Winding Road: Civil Repair of Intimate Injustice. Sociological Theory, 19(3), pp. 371-400.

5. Alexander, J. 2006. Cultural Pragmatics: Social Performance Between Ritual and Strategy. In: J. Alexander, B. Giesen ed. Social Performance. Symbolic Action, Cultural Pragmatics and Rituals. Cambridge: University Press.

6. Cordero, R., Carballo, F. and Ossandón, J., 2008. Interview. Performing Cultural Sociology. A Conversation with Jeffrey Alexander, European Journal of Social Theory, 11(4), pp. 523-542.

\section{Інформація про авторів}

Пасісниченко Віктор Леонідович - кандидат філософських наук, доцент кафедри політології, соціології і культурології Харківського національного педагогічного університету імені Г.С. Сковороди; e-mail: viktorpasisn@gmail.com; ORCID: http://orcid.org/0000-0002-6849-8672.

Пасісниченко Ірина Миколаӥвна - кандидат філософських наук, доцент кафедри політології, соціології і культурології Харківського національного педагогічного університету імені Г.С. Сковороди; e-mail: irinapasis@gmail.com; ORCID: http://orcid.org/0000-0002-8899-848X.

Стаття надійшла до редакції: 21.02.2019 р. $\quad$ Прийнята до друку: 07.03.2019 p. 